\title{
Feed Intake, Nutrient Digestibility, Antioxidant Activity in Plasma, and Growth Performance of Male Dairy Cattle Fed Black Rice and Purple Corn Extracted Residue
}

\author{
R. Prommachart ${ }^{\mathrm{a}}$, J. Uriyapongson ${ }^{\mathrm{b}}$, A. Cherdthong ${ }^{\mathrm{a}}$, \& S. Uriyapongson ${ }^{\mathrm{a}, *}$ \\ aDepartment of Animal Science, Faculty of Agriculture, Khon Kaen University, \\ bDepartment of Food Technology, Faculty of Technology, Khon Kaen University, \\ Khon Kaen 40002, Thailand \\ *Corresponding author: suthipng@kku.ac.th \\ (Received 28-08-2020; Revised 14-12-2020; Accepted 06-01-2021)
}

\begin{abstract}
The study aimed to evaluate the impact of black rice and purple corn extracted residue (BPER) on feed intake, nutrient digestibility, growth performance, and antioxidant activity in male dairy cattle. The residue after extraction of anthocyanin from black rice and purple corn contains anthocyanin and phenolic acids. Several researchers found that anthocyanins and phenolic acids had antioxidant and antimicrobial functions in animals. Sixteen male dairy cattle (with average body weight of $\mathbf{1 6 0}$ $\pm 10.6 \mathrm{~kg}$ ) were allotted in a completely randomized design (CRD) with 4 levels of black rice and purple corn extracted residue (BPER) at $0 \%, 2 \%, 4 \%$, and $6 \%$ dry matter (DM) in total mixed ration (TMR). The TMR diets were fed ad libitum for 125 days. The daily DM intake, nutrient digestibility, growth performance, and plasma metabolites were measured. The results showed that BPER up to $6 \%$ had no effect on intakes of DM, organic matter (OM), crude protein $(\mathrm{CP})$, neutral detergent fiber (NDF), and acid detergent fiber (ADF). Intake of ether extract (EE) increased with higher levels of BPER ( $p<0.05)$. The DM, OM, CP, NDF, and ADF digestibility were similar among treatments. The average daily gain (ADG) and feed per gain were similar among treatments. There was no effect of BPER on the concentrations of glucose, urea, total cholesterol, aspartate aminotransferase (AST), alanine aminotransferase (ALT), protein carbonyl, and antioxidant activity in the plasma. However, the malondialdehyde (MDA) concentrations in the plasma decreased $(p<0.05)$ with the increased level of BPER, indicating that lower lipid oxidation compared to $0 \%$ BPER. It was concluded that BPER can be used up to $6 \%$ to reduce oxidative stress, without any negative effect on feed intake and nutrient digestibility.
\end{abstract}

Keywords: male dairy cattle; black rice and purple corn extracted residue; black rice bran residue; purple corn cob; digestibility; antioxidant

\section{INTRODUCTION}

Crossbreeding of Holstein Friesian cattle is the most common breeding of dairy cattle in Thailand. The purpose of this crossbred is to improve the milk yield of Bos Taurus cattle having heat tolerance and resistance to tropical diseases. However, humidity, high levels of solar irradiance, and the air temperature of tropical locations negatively affect dairy cattle, causing heat stress in Bos Taurus cattle (Butt et al., 2019). This heat stress condition generates free radicals, leading to oxidative stress (Akbarian et al., 2016), which is the cause of chronic health problems in animals (Modzelewska-Kapituła et al., 2018). Diets containing antioxidant compounds have antioxidative effects in decomposing and scavenging free radicals in cattle. As a result, there will be a balance between antioxidants and free radicals in the body (Ribeiro et al., 2019).

Anthocyanins are the natural antioxidants having more antioxidant activities than vitamin E.
Anthocyanins are found in plant pigments with a stable red-colored form under acidic condition and turn to blue-colored in the presence of a base condition (Fei et al., 2021). The darker color could be explained by the high concentration of anthocyanin (Cömert et al., 2020). Several researchers found that anthocyanins have antimicrobial effects that can act on the cytoplasmic membrane of bacteria and change its structure and function, leading to the loss of structural integrity of the cell membrane and they also play a role as antioxidants that their structures can be able to donate electrons to the free radicals with unpaired electrons and reduce agents in the pathway of electron-transfer reaction (Bendokas et al., 2020; Prommachart et al., 2020).

In Thailand, black rice (Oryza sativa L.) and purple corn (Zea mays L.) are important sources having the potential to be used as functional foods having antioxidants and food colorants because they are rich in anthocyanin and phenolic compounds (Kapcum et al., 2018). Several studies reported the application of black 
rice and purple corn. For example, supplementation of anthocyanin-rich purple corn extract orally improved oxidative stress status in rats (Kirisattayakul et al., 2017), and oral supplementation of black-rice extract reduced oxidative stress status in humans and rats (Sangkitikomol et al., 2010). In addition, the studies in the meat showed that black-rice extract retarded lipid oxidation and increased oxidative stability during storage of ground beef patties (Prommachart et al., 2020), steak beef (Purba et al., 2020), and pork patties (Park et al., 2017). For these reasons, anthocyanin extracts from black rice and purple corn are produced industrially in response to consumer's demands. Consequently, after extract processing, there are a lot of agro-industrial residues from black rice and purple corn. On the contrary, residues from the extraction of anthocyanin still contain anthocyanin similar to those reported in grape pomace (Trikas et al., 2016) and blackberry (Yamashita et al., 2017).

Feeding agro-industrial residues to livestock reduce not only environmental problems caused by the accumulation of residues and decreases the carbon footprints of animal production (Gerber et al., 2014) but also improve antioxidant status in animal (Tian et al., 2019) due to the presence of bioactive compounds such as phytochemicals and vitamins.

Although the anthocyanin extracted from black rice and purple corn have antimicrobial and antioxidant functions, to the best of our knowledge, no published research has evaluated its by-product effect on improving antioxidant status to enhance the growth performance of cattle. Therefore, the objectives of this study were to evaluate the effect of black rice and purple corn extracted residue (BPER) on feed intake, nutrient digestibility, growth performance, and antioxidant activity in male dairy cattle.

\section{MATERIALS AND METHODS}

\section{Animals, Treatments, and Experimental Design}

This experiment was conducted at the Department of Animal Science, Khon Kaen University, Thailand. Regarding animal care, the guidelines recommended by the Animal Ethics Committee of Khon Kaen University were followed (U1-04090-2559). Sixteen males Holstein cattle (7-8 months) with an average body weight of $160 \pm 10.6 \mathrm{~kg}$ were randomly assigned into one of four treatment groups (4 cattle per treatment) according to a completely randomized design (CRD). The cattle were raised 30 days for adaptation with ad libitum of TMR diet. The animals were kept indoors, housing with individual pens $(2.5 \mathrm{~m} \times 5 \mathrm{~m})$ with concrete floors that were cleaned every morning. The water was available at all times. During the 125 days of the feeding trial, the BPER was added to TMR diets at the levels of $0,2,4$, and $6 \%$, respectively. All experimental cattle received experimental diets ad libitum twice a day. The TMR was formulated to provide $12 \%$ crude protein and $15 \mathrm{MJ} / \mathrm{kg}$ gross energy to meet the nutrient requirements of growing male dairy cattle according to NRC (2001). The ingredients and chemical composition of the experimental diets are shown in Table 1 and Table 2. The BPER was the residue consisted of $80 \%$ black-rice bran and $20 \%$ purple-corn cob (This proportion was taken by the manufacturing process) and obtained from Siam Miragro Company Limited, Khon Kean, Thailand. Digestibility was determined with external markers with chromic oxide $\left(\mathrm{Cr}_{2} \mathrm{O}_{3}\right)$ according to the method described by de Souza et al. (2015). Briefly, a daily dose in paper capsule containing $10 \mathrm{~g}$ of $\mathrm{Cr}_{2} \mathrm{O}_{3}$ as a marker was orally administered in a single daily dose at the same time in the morning before feeding on day 110 to 120 of feeding trial.

\section{Data Collection and Sample Analysis}

Feed offered and feed refusals of the individual animals were recorded daily. The animals were weighed every 30 days before morning feeding for determination of weight gain. Feed efficiency was calculated by using feed intake and weight gain. Feed samples and fecal samples (grabbing sample technique) were collected on days 114 to 120 of the feeding trial. All samples were kept in plastic bags and stored at $-20^{\circ} \mathrm{C}$ for subsequent analyses. Feed and fecal samples were dried at $60^{\circ} \mathrm{C}$ for 48 hours and ground prior to proximate analysis. At the end of the experiment, the samples were taken to the Nutrition Laboratory at the Department of Animal Science, Khon Kaen University and analyzed for DM (at $100^{\circ} \mathrm{C}$ for 24 hours) according to AOAC (1995); CP was determined by total nitrogen determination using a 6.25 conversion factor according to Kjeldahl method of AOAC (1995); EE was determined by Soxhlet instrument using petroleum ether extract (AOAC, 1995); ash was determined (at $550^{\circ} \mathrm{C}$ for 6 hours) according to AOAC (1995); NDF and ADF in samples were analyzed using amylase and sodium sulfite according to Van Soest et al. (1991) procedures; ADL (in $12 \mathrm{M} \mathrm{H}_{2} \mathrm{SO}_{4}$ for 3 hours) was determined according to Van Soest \& Robertson (1980). The quantification of $\mathrm{Cr}_{2} \mathrm{O}_{3}$ in fecal samples was performed by the method described by Fenton \& Fenton (1979). Briefly, $1 \mathrm{~g}$ of feed and feces samples were ashed at $600^{\circ} \mathrm{C}$ for 1 hour. After cooling, $15 \mathrm{~mL}$ of a digestion mixture was added to the samples and heated until a yellowness or redness. The digests were transferred to $250 \mathrm{~mL}$ volumetric flasks with distilled water and made up to volume. Stand overnight to allow suspended material to settle, then $10 \mathrm{~mL}$ of the diluted digest was centrifuged and measured at $370 \mathrm{~nm}$ using spectrophotometry to determine the $\mathrm{Cr}_{2} \mathrm{O}_{3}$ content compared with a standard curve. Organic matter (OM), cellulose, and hemicellulose were calculated using the following formulas, respectively: $\mathrm{OM}=100$ - ash; hemicellulose $=$ NDF - ADF; cellulose $=$ ADF - ADL. The GE levels of feed samples were measured using Isoperibol Bomb Calorimeter AC500 (Leco, Michigan, USA). Dry matter intake (DMI) was calculated at kg/day. Average daily feed intake (ADFI) was determined by dividing the total feed intake in terms of the days of trial and the number of each animal, expressed as a DM basis. The average daily gain (ADG) was calculated by dividing body weight gain based on the number of days.

The bioactive compounds of feed and BPER were determined by using samples (0.2 g) extracted twice 
with $10 \mathrm{~mL}$ of acidified methanol dissolved in $1.0 \mathrm{~N}$ $\mathrm{HCl}(85: 15 \mathrm{v} / \mathrm{v})$ and incubated at room temperature for 2 hours with shaking. The extracts were centrifuged at $3,000 \mathrm{rpm}$ at $4^{\circ} \mathrm{C}$ for 10 minutes, and the clear supernatants were collected into a volumetric flask. The total phenolic content in the feed and BPER were determined using Folin-Ciocalteu method (Ainsworth \& Gillespie, 2007). Briefly, $200 \mu \mathrm{L}$ of the extract was mixed with 600 $\mu \mathrm{L}$ Folin-Ciocalteu reagent $(10 \%)$ and stood at room temperature for 5 minutes; $500 \mu \mathrm{L}$ of $\mathrm{Na}_{2} \mathrm{CO}_{3}(700 \mathrm{mM})$ solution was added to the mixture and incubated at room temperature for 2 hours. The absorbance was measured at $765 \mathrm{~nm}$ via a spectrophotometer. Gallic acid was used as the calibration standard, and the total phenolic content was expressed as milligrams of gallic acid equivalent (GAE) per gram of dry weight.

Total anthocyanin content was determined by the pH-differential method according to Lee et al. (2005). Briefly, two aliquots $(0.5 \mathrm{~mL})$ of the extracts were diluted $(4.5 \mathrm{~mL})$ with buffer reagents $(0.025 \mathrm{M}$ potassium chloride at $\mathrm{pH}_{1.0}$ and $0.4 \mathrm{M}$ sodium acetate at $\mathrm{pH}_{4.5}$ ) and incubated in the dark for 20 minutes at room temperature. The absorbance was measured at 520 and $700 \mathrm{~nm}$, respectively, using a UV1280-Vis Spectrophotometer (Shimadzu, Kyoto, Japan). The results were expressed in $\mathrm{mg}$ of cyanidin-3-O-glucoside equivalents per g dry weight using the equation:

Anthocyanins content (cyaniding-3-glucoside equivalents, $\mathrm{mg} / \mathrm{L})=\mathrm{A} \times \mathrm{MW} \times \mathrm{DF} \times 10^{3} /(\varepsilon \times 1)$

where $\mathrm{A}$ was $\mathrm{pH}_{1.0}(\mathrm{~A} 520 \mathrm{~nm}-\mathrm{A} 700 \mathrm{~nm})-\mathrm{pH}_{4.5}(\mathrm{~A} 520$ $\mathrm{nm}$-A700 nm), MW was molecular weight of cyanidin3-glucoside $(449.2 \mathrm{~g} / \mathrm{mol})$, DF was dilution factor, $10^{3}$ was factor for conversion from $\mathrm{g}$ to $\mathrm{mg}, \varepsilon$ was molar extinction coefficient of cyanidin-3-glucoside $\left(26,900 \mathrm{M}^{-1}\right.$. $\left.\mathrm{cm}^{-1}\right)$, and 1 was the path length $(\mathrm{cm})$.

\section{Blood Sample Collection and Analysis}

Blood samples for the plasma profile analyzed from each individual cow were collected before the morning meal at day 120 of the feeding trial by jugular venipuncture for $5 \mathrm{~mL}$ with a EDTA collection tube. The EDTAplasma was separated by centrifugation (1500 rpm, $15 \mathrm{~min}$ ), and stored at $-80^{\circ} \mathrm{C}$ until analysis. The Roche cobas c501 automated analyzer (Roche Diagnostics Ltd, Rotkreuz, Switzerland) was used for quantification of total cholesterol (TC, enzymatic colorimetric CHODPAP method) and high-density lipoprotein cholesterol (HDL, enzymatic colorimetric PE-GPO-PAP method) concentrations. Plasma glucose $(\mathrm{mg} / \mathrm{mL})$, urea nitrogen $(\mathrm{mg} / \mathrm{dL})$, aspartate aminotransferase (AST, IU/L), and alanine aminotransferase (ALT, IU/L) were measured with enzymatic methods (Srinagarind Hospital, Faculty of Medicine of Khon Kaen University, Khon Kaen, Thailand).

The antioxidant capacity was determined by spectrophotometry in accordance with the method of Martinez et al. (2006), using a stable free radical adiphenyl-b-picrylhydrazyl (DPPH). Briefly, $100 \mu \mathrm{L}$ of plasma was mixed with $400 \mu \mathrm{L}$ of methanol and centrifuged at $12,000 \mathrm{rpm}$ at $4^{\circ} \mathrm{C}$ for 20 minutes to separate the proteins. The analysis was performed in microplates by adding $200 \mu \mathrm{L}$ of $0.115 \mathrm{mM}$ DPPH solution (dissolved in methanol) to $100 \mu \mathrm{L}$ of clear supernatant and incubated in dark for 1 hour at room temperature. The absorbance was measured at $517 \mathrm{~nm}$ using a UV-Vis spectrophotometer (SpectraMax® M3 Multi-Mode Microplate Reader, Molecular Devices, San Jose, CA, USA). The absorbance of DPPH with methanol (control sample) was used for a baseline measurement. The DPPH scavenging activity was calculated using the following equation: DPPH scavenging activity $(\%)=[(\mathrm{Ac}-\mathrm{As}) / \mathrm{Ac}] \times 100$

where Ac is the absorbance of the control (DPPH solution with methanol) and As is the absorbance of the sample.

The lipid oxidation of plasma was determined with the malondialdehyde (MDA) using thiobarbituric acid reactive substances (TBARS), as described by Toaldo et al. (2015). Briefly, aliquots $(200 \mu \mathrm{L})$ of plasma were acidified with $500 \mu \mathrm{L}$ of $20 \%$ trichloroacetic acid (TCA) and $50 \mu \mathrm{L}$ of $10 \mathrm{mM}$ BHT. The $500 \mu \mathrm{L}$ of Thiobarbituric acid $(55 \mathrm{mM})$ were added to the samples and incubated at $100^{\circ} \mathrm{C}$ in a water bath for 45 minutes. The samples were cooled on ice for 5 minutes, $1.5 \mathrm{~mL}$ of $\mathrm{n}$-butanol were added and the mixtures were centrifuged at 10,000 rpm at $4^{\circ} \mathrm{C}$ for 10 minutes to obtain a clear supernatant. The absorbance was measured at $532 \mathrm{~nm}$ via a UV1280Vis Spectrophotometer (Shimadzu, Kyoto, Japan) by running a blank that contained all reagents, except the plasma sample. The results were calculated as TBARS concentration expressed in $\mu \mathrm{molL}^{-1}$ of MDA using the molar extinction coefficient of the pink TBA chromagen as $1.56 \times 10^{-5} / \mathrm{M} / \mathrm{cm}$.

The protein oxidation of plasma was assessed by assayed protein carbonyl using 2,4-dinitrophenylhydrazine (DNPH) base on the method of Patsoukis et al. (2004). Briefly, four aliquots of $100 \mu \mathrm{L}$ of plasma were distributed in Eppendorf tubes. All aliquots were mixed with $1 \mathrm{~mL}$ of ice-cold TCA (10\%) for 15 minutes in ice-baths to precipitate the proteins. The tube samples were centrifuged at $6,000 \mathrm{rpm}$ for 10 minutes at $4^{\circ} \mathrm{C}$ to discard the clear supernatant. TCA $(10 \%)$ was added $(1$ $\mathrm{mL}$ ) to the pellets, and the procedures described above were repeated. After removing the supernatant, $500 \mu \mathrm{L}$ of $10 \mathrm{mM}$ DNPH (dissolved in $2.0 \mathrm{M} \mathrm{HCl}$ ) were added to the pellets of two aliquots, and $500 \mu \mathrm{L}$ of $\mathrm{HCl}(2.0 \mathrm{M})$ without DNPH were added to the pellet of two aliquots for blank. All samples were mixed and left in the dark for 1 hour, vortexed every 10 minutes to be derivative. Subsequently, $500 \mu \mathrm{L}$ of TCA $20 \%$ was added to all samples, which were then vortexed, placed in ice baths for 15 minutes, and centrifuged at 8,000 rpm for 10 minutes in $4^{\circ} \mathrm{C}$. The resulting supernatant was discarded. To remove excess DNPH, protein pellets were washed three times with $1 \mathrm{~mL}$ of ethanol: ethyl acetate $(1: 1, \mathrm{v} / \mathrm{v})$, vortexed, and centrifuged at 8,000 rpm for 10 minutes in $4^{\circ} \mathrm{C}$. After each wash, the supernatant was discarded. After the final wash, the samples were left under the hood for 20 minutes to remove the excess solvent, and the pellets were subsequently dissolved in $1.5 \mathrm{~mL}$ of $6.0 \mathrm{M}$ guanidine hydrochloride (dissolved in $20 \mathrm{mM}$ phosphate buffer, $\mathrm{pH}$ 6.5) and placed in the dark 
for 30 minutes and vortexed every 10 minutes. Finally, the sample solution was centrifuged at 12,000 rpm for 10 minutes at $4^{\circ} \mathrm{C}$ to remove insoluble material. The carbonyl concentration in the samples was measured using spectrophotometry with absorbance at $370 \mathrm{~nm}$ and 280 $\mathrm{nm}$ using a UV1280-Vis Spectrophotometer (Shimadzu, Kyoto, Japan). The concentration of protein carbonyl was expressed as nmol carbonyl per mg protein (nmol/ mg protein) and calculated using the following equation (Levine et al., 1994):

$\begin{aligned} \mathrm{C}_{\text {hydrazone }} / \mathrm{C}_{\text {protein }}= & \left\{\mathrm{A} 370 /\left[\varepsilon_{\text {hydrazone }, 370} \times\left(\mathrm{A}_{280}-\mathrm{A}_{370} \times 0.43\right)\right]\right\} \times \\ & 10^{6}[\mathrm{nmol} / \mathrm{mg} \text { protein }]\end{aligned}$

where $\varepsilon_{\text {hydrazone }} 370$ is $22,000 \mathrm{M}^{-1} \mathrm{~cm}^{-1}$ and 0.43 is $\varepsilon_{\text {hydrazone,280 }} / \varepsilon_{\text {hydrazone,370 }}$

\section{Statistical Analysis}

All data were statistically analyzed through analysis of variance (ANOVA) using the generalized linear model (GLM) procedure of the Statistical Analysis System (SAS, 1998). Results were presented as mean values with the standard error of the means. Orthogonal polynomials were used to evaluate for each parameter to determine linear and quadratic responses to supplementation of BPER, with the level of significance at $\mathrm{p}<0.05$.

\section{RESULTS}

\section{Chemical Composition}

Feed ingredients and chemical compositions of treatment diets are presented in Table 1 and Table 2. The DM, organic matter (OM), crude protein $(\mathrm{CP})$, ash, NDF, ADF, acid detergent lignin (ADL), hemicellulose, cellulose, and GE were similar in all treatments. The average total phenolic and anthocyanin content in BPER were $8.23 \mathrm{mg}$ of gallic acid/g and $1.05 \mathrm{mg}$ of cyanidin3-O-glucoside equivalents per $\mathrm{g}$ dry weight, respec-

Table 1. Ingredients of experimental total mixed ration (TMR) diets

\begin{tabular}{lcccc}
\hline \multirow{2}{*}{ Ingredient composition $(\mathrm{g} / \mathrm{kg} \mathrm{DM})$} & \multicolumn{3}{c}{ BPER, \% of dietary DM } \\
\cline { 2 - 5 } & 0 & 2 & 4 & 6 \\
\hline Cassava pulp & 300 & 300 & 300 & 300 \\
King Napier grass silage & 243 & 243 & 243 & 243 \\
Palm kernel meal & 140 & 140 & 140 & 140 \\
Cassava chip & 110 & 110 & 110 & 110 \\
Dried distillers corn grains with solubles & 80 & 80 & 80 & 80 \\
Defatted rice bran & 100 & 80 & 40 & 40 \\
Black rice and purple corn extracted residue & - & 20 & 60 \\
Salt & 5 & 5 & 5 & 5 \\
Sulfur & 2 & 2 & 5 & 2 \\
Dicalcium phosphate & 5 & 5 & 5 & 5 \\
Premix & 5 & 5 & 10 & 5 \\
Urea & 10 & 10 & 1000 & 10 \\
Total & 1000 & 1000 & 5 \\
\hline
\end{tabular}

Note: $\mathrm{BPER}=$ black rice and purple corn extracted residue; $\mathrm{DM}=\mathrm{dry}$ matter; ${ }^{*}=$ Each kilogram of premix contained the following: vitamin $\mathrm{A}=3,000,000$ IU; vitamin D= 600,000 IU; vitamin E= 9,000 IU; Fe= $50 \mathrm{~g} ; \mathrm{Zn}=40 \mathrm{~g} ; \mathrm{Mn}=40 \mathrm{~g} ; \mathrm{Co}=0.1 \mathrm{~g} ; \mathrm{Cu}=10 \mathrm{~g} ; \mathrm{Se}=0.1 \mathrm{~g}$; I= $0.5 \mathrm{~g}$.

Table 2. Analyzed chemical composition and fatty acid profile of total mixed ration diets

\begin{tabular}{lccccc}
\hline \multirow{2}{*}{ Chemical composition (g/kg DM) } & \multicolumn{4}{c}{ BPER, \% of dietary DM } \\
\cline { 2 - 5 } & 0 & 2 & 4 & 6 \\
\hline Dry matter (DM, g/kg fresh weight) & 387 & 392 & 395 & 385 & 938 \\
Organic matter (OM) & 937 & 938 & 939 & 939 & 955 \\
Crude protein (CP) & 124 & 128 & 123 & 125 & 137 \\
Ether extract (EE) & 23 & 27 & 33 & 36 & 128 \\
Ash & 62 & 62 & 61 & 61 & 102 \\
Neutral detergent fiber (NDF) & 432 & 437 & 424 & 423 & 325 \\
Acid detergent fiber (ADF) & 246 & 238 & 241 & 239 & 110 \\
Acid detergent lignin (ADL) & 53 & 55 & 52 & 54 & 36 \\
Hemicellulose (NDF-ADF) & 186 & 189 & 183 & 184 & 215 \\
Cellulose (ADF-ADL) & 193 & 188 & 192 & 187 & 74 \\
Gross energy (MJ/kg DM) & 15.23 & 15.13 & 15.29 & 15.2 & 17.29 \\
Anthocyanins (mg/g DM) & ND & 0.02 & 0.04 & 0.05 & 1.05 \\
Total phenolic acid (mg gallic acid/g DM) & 2.67 & 2.8 & 3.01 & 3.31 & 8.23 \\
\hline
\end{tabular}

Note: $\mathrm{BPER}=$ black rice and purple corn extracted residue; $\mathrm{ND}=$ not detected; $\mathrm{TMR}=$ total mixed ration. 
tively. The anthocyanin and total phenolic acid contents increased with a higher level of BPER in diet treatments, whereas the anthocyanin was not detected in the control sample $(0 \%$ supplementation).

\section{Feed Intake, Digestibility, and Growth Performances}

The effects of BPER in the diet on feed intake are presented in Table 3. The results showed that BPER supplementation had no effect on total feed and nutrient intakes; however, fat intake increased with a higher level of BPER $(p<0.05)$. The effects of BPER on the apparent digestibilities are presented in Table 4. There were no significant differences in apparent digestibilities of $\mathrm{DM}, \mathrm{OM}, \mathrm{CP}, \mathrm{NDF}$, and ADF. The growth performances of cattle are presented in Table 6 . The final body weight, weight gain, average daily gain, and feed per gain were similar in all treatments.

\section{Plasma Metabolite Profiles}

The effects of BPER in the diet on plasma metabolite profiles are presented in Table 5. There were no significant effects of BPER supplementation on plasma concentrations of glucose, blood urea nitrogen, TC, HDL-cholesterol, AST, ALT, and antioxidant activity. However, MDA concentration was significantly different and linearly decreased with a higher level of BPER $(\mathrm{p}<0.05)$. Even though the higher values of BPER in the diets showed a slightly lower protein carbonyl, this difference was not statistically significant $(\mathrm{p}=0.07)$.

\section{DISCUSSION}

\section{Bioactive Compounds of the Diets}

The BPER in this experiment is the mixture of $80 \%$ black rice bran and $20 \%$ purple corn cob. This BPER contains $1.05 \mathrm{mg} / \mathrm{g}$ of anthocyanins and $8.25 \mathrm{mg}$ gallic acid/g phenolic acid which are group of flavonoid compounds. Anthocyanins had high antioxidant activity (Cömert et al., 2020) and could enhance antioxidant enzyme activity (Hosoda et al., 2012a). Previous studies indicated that anthocyanin was not degraded during the fermentation process in the rumen (Tian et al., 2018). In this experiment, BPER contained anthocyanin similar to those reported by Laokuldilok et al. (2011) at 1.13-2.56 $\mathrm{mg} / \mathrm{g}$ of anthocyanin and $9.9 \%$ DM total phenolic acid for black rice bran. This concentration was higher than that reported by Hosoda et al. (2012b), who fed purple rice silage with anthocyanins concentration at 0.23 $\mathrm{mg} / \mathrm{g}$ to sheep to improve oxidative status. It has been considered that BPER had bioactive ingredients and had potential antioxidant activity.

\section{Effect of BPER on Intake and Digestibility of the Diets}

Increasing BPER in the diet had no effect on DM intake and DM digestibility. The intake of $\mathrm{CP}, \mathrm{NDF}$, and ADF followed a similar pattern to DM intake. This might be because the BPER had no effect on cattle in terms of feed-sorting behavior and other factors which could be related to their behaviors. Several related fac-

Table 3. Voluntary feed intake and nutrient intake of male dairy cattle fed black rice and purple corn extracted residue in total mixed ration diets

\begin{tabular}{|c|c|c|c|c|c|c|c|}
\hline \multirow{2}{*}{ Variables } & \multicolumn{4}{|c|}{ BPER supplemented (\%) } & \multirow{2}{*}{ SEM } & \multicolumn{2}{|c|}{ Trend } \\
\hline & 0 & 2 & 4 & 6 & & $\mathrm{~L}$ & Q \\
\hline \multicolumn{8}{|l|}{ Total feed intake (kg of DM) } \\
\hline $\mathrm{kg} / \mathrm{d}$ & 6.65 & 6.84 & 7.23 & 7.08 & 0.44 & 0.45 & 0.72 \\
\hline$\% B W$ & 2.66 & 2.73 & 2.80 & 2.68 & 0.06 & 0.68 & 0.20 \\
\hline $\mathrm{g} / \mathrm{kgBW} 0.75$ & 105.32 & 108.16 & 111.84 & 107.58 & 2.75 & 0.44 & 0.25 \\
\hline \multicolumn{8}{|c|}{ Nutrient intake (kg DM/day) } \\
\hline Organic matter & 6.23 & 6.42 & 6.79 & 6.65 & 0.41 & 0.44 & 0.72 \\
\hline Crude protein & 0.86 & 0.89 & 0.89 & 0.85 & 0.05 & 0.95 & 0.62 \\
\hline Ether extract & 0.15 & 0.18 & 0.23 & 0.22 & 0.01 & 0.001 & 0.16 \\
\hline Neutral detergent fiber & 2.87 & 2.99 & 3.06 & 2.99 & 0.24 & 0.64 & 0.65 \\
\hline Acid detergent fiber & 1.63 & 1.62 & 1.74 & 1.69 & 0.1 & 0.59 & 0.85 \\
\hline
\end{tabular}

Note: $\mathrm{SEM}=$ standard error of means; $\mathrm{L}=$ linear, $\mathrm{Q}=$ quadratic; $\mathrm{BPER}=$ black rice and purple corn extracted residue; $\mathrm{TMR}=$ total mixed ration; $\mathrm{DM}=\mathrm{dry}$ matter.

Table 4. Apparent digestibility of male dairy cattle fed black rice and purple corn extracted residue in total mixed ration diets

\begin{tabular}{|c|c|c|c|c|c|c|c|}
\hline \multirow{2}{*}{ Digestibility, \% } & \multicolumn{4}{|c|}{ BPER, $\%$ of dietary DM } & \multirow{2}{*}{ SEM } & \multicolumn{2}{|c|}{ Trend } \\
\hline & 0 & 2 & 4 & 6 & & $\mathrm{~L}$ & Q \\
\hline Dry matter & 68.01 & 66.45 & 66.16 & 67.87 & 1.85 & 0.93 & 0.41 \\
\hline Organic matter & 81.71 & 82.01 & 81.63 & 79.84 & 2.21 & 0.55 & 0.64 \\
\hline Crude protein & 61.22 & 60.56 & 57.29 & 61.33 & 2.61 & 0.82 & 0.41 \\
\hline Neutral detergent fiber & 49.46 & 48.61 & 47.63 & 48.03 & 2.74 & 0.69 & 0.83 \\
\hline Acid detergent fiber & 40.68 & 38.57 & 38.02 & 39.79 & 3.12 & 0.83 & 0.56 \\
\hline
\end{tabular}

Note: $\mathrm{SEM}=$ standard error of means; $\mathrm{L}=$ linear; $\mathrm{Q}=$ quadratic; $\mathrm{BPER}=$ black rice and purple corn extracted residue; $\mathrm{TMR}=$ total mixed ration; $\mathrm{DM}=\mathrm{dry}$ matter. 
Table 5. Plasma metabolite, liver enzymes, lipid oxidation, protein carbonyl, and antioxidant activities of male dairy cattle fed black rice and purple corn extracted residue in total mixed ration diets

\begin{tabular}{|c|c|c|c|c|c|c|c|}
\hline \multirow{2}{*}{ Variables } & \multicolumn{4}{|c|}{ ARE, $\%$ of dietary DM } & \multirow{2}{*}{ SEM } & \multicolumn{2}{|c|}{ Trend } \\
\hline & 0 & 2 & 4 & 6 & & $\mathrm{~L}$ & Q \\
\hline Glucose (mg/dL) & 80.00 & 85.66 & 83.50 & 79.00 & 2.41 & 0.68 & 0.09 \\
\hline Urea nitrogen (mg/dL) & 7.00 & 5.75 & 5.75 & 6.00 & 0.90 & 0.50 & 0.43 \\
\hline Total cholesterol (mg/dL) & 99.00 & 103.50 & 99.07 & 92.25 & 8.25 & 0.56 & 0.50 \\
\hline HDL- cholesterol (mg/dL) & 85.66 & 88.00 & 86.50 & 82.25 & 6.83 & 0.72 & 0.65 \\
\hline AST(IU/L) & 52.25 & 48.67 & 48.25 & 56.00 & 4.48 & 0.60 & 0.25 \\
\hline ALT (IU/L) & 20.50 & 19.50 & 20.25 & 21.33 & 1.74 & 0.70 & 0.57 \\
\hline MDA (umol/L) & 0.47 & 0.38 & 0.28 & 0.30 & 0.05 & 0.02 & 0.26 \\
\hline Carbonyl protein (umol/L) & 2.66 & 2.42 & 2.28 & 2.04 & 0.21 & 0.07 & 0.98 \\
\hline Antioxidant activity (\%DPPH) & 8.96 & 7.68 & 9.76 & 9.27 & 0.92 & 0.47 & 0.67 \\
\hline
\end{tabular}

Note: $\mathrm{SEM}=$ standard error of means; $\mathrm{L}=$ linear; $\mathrm{Q}=$ quadratic; $\mathrm{AST}=$ aspartate aminotransferase; $\mathrm{ALT}=$ alanine aminotransferase; $\mathrm{MDA}=$ malondialdehyde; $\mathrm{BPER}=$ black rice and purple corn extracted residue; $\mathrm{TMR}=$ total mixed ration; $\mathrm{DM}=$ dry matter.

Table 6. Growth performance of male dairy cattle fed black rice and purple corn extracted residue in total mixed ration diets

\begin{tabular}{|c|c|c|c|c|c|c|c|}
\hline \multirow{2}{*}{ Variables } & \multicolumn{4}{|c|}{ BPER, $\%$ of dietary DM } & \multirow{2}{*}{ SEM } & \multicolumn{2}{|c|}{ Trend } \\
\hline & 0 & 2 & 4 & 6 & & $\mathrm{~L}$ & Q \\
\hline Initial body weight, $\mathrm{kg}$ & 161.85 & 157.77 & 167.33 & 170.57 & 11.37 & 0.53 & 0.77 \\
\hline Final body weight, kg & 351.37 & 351.80 & 355.33 & 365.07 & 22.80 & 0.69 & 0.85 \\
\hline Weight gain, $\mathrm{kg}$ & 189.52 & 193.92 & 188.00 & 194.50 & 12.18 & 0.87 & 0.93 \\
\hline Average daily gain, $\mathrm{kg}$ & 1.51 & 1.55 & 1.50 & 1.55 & 0.09 & 0.87 & 0.93 \\
\hline \multicolumn{8}{|l|}{ Feed per gain } \\
\hline Dry matter intake & 4.41 & 4.42 & 4.81 & 4.53 & 0.14 & 0.30 & 0.36 \\
\hline Organic matter intake & 4.13 & 4.14 & 4.54 & 4.25 & 0.13 & 0.24 & 0.28 \\
\hline Crude protein intake & 0.55 & 0.56 & 0.59 & 0.56 & 0.02 & 0.30 & 0.20 \\
\hline
\end{tabular}

Note: $\mathrm{SEM}=$ standard error of means; $\mathrm{L}=$ linear; $\mathrm{Q}=$ quadratic; $\mathrm{BPER}=$ black rice and purple corn extracted residue; $\mathrm{TMR}=$ total mixed ration; $\mathrm{DM}=\mathrm{dry}$ matter.

tors, including ruminal $\mathrm{pH}$, volatile fatty acid profile, digesta flow rate, fiber digestion, and palatability, can affect cattle's feed intake (Hassan et al., 2016).

Because flavonoid compounds are amphipathic molecules contained both hydrophilic and hydrophobic groups, they can interact with both the hydrophobic cores and the hydrophilic head groups of the lipid membranes, resulting in a high affinity with lipid compounds (Šturm \& Poklar Ulrih, 2020). Therefore, the increase of flavonoid-compounds intake included anthocyanin and other phenolic compounds, will also result in the increase of ether extract intake (See Table 3). Similarly, Pereira et al. (2008) reported that steers fed Brachiaria brizantha silage (rich-flavonoid) had a higher intake of ether extract.

This result was similar to Oliveira et al. (2010), who reported that polyphenol-rich extract of dried pomegranate (5 to $10 \mathrm{~g} /$ day) had no impact on intake and DM digestibility, but it reduced the fat and protein digestions of calves. In addition, Hosoda et al. (2012a) reported that anthocyanin-rich corn silage had no effect on DM intake and total digestible nutrient intake of lactating dairy cows. These reported results might indicate that anthocyanin has no negative effect on the feed intake of ruminants.

However, the in vitro antimicrobial effect of anthocyanin had been reported (Zhao et al., 2009). A high concentration of anthocyanins could have negative effects on microbial fermentation in the rumen of cattle, leading to the decreased nutrient digestibility. In this experiment, the BPER supplementation up to $6 \%$ in diets had no effect on the digestibility of DM, OM, NDF, and ADF. Therefore, the anthocyanin concentration in treatment diets might not be high enough to interfere with microbes in the rumen.

\section{Plasma Metabolite}

High intake of dietary energy could enhance mitochondrial free radical production, which causes oxidative stress (Fang et al., 2002). Therefore, in this experiment, feeding TMR diets at ad libitum might increase the risk of oxidative stress. Plasma antioxidant activity is an indicator of the antioxidant status in the animal. The phenolic compounds were absorbed through the intestine of the digestive tract; a great variety of phenolic substances of plasma can enhance antioxidant capacity (Ishida et al., 2015). Safari et al. (2018) reported that pomegranate by-product in the diets improved total antioxidant status in the plasma of dairy cows. However, in the present study, the plasma antioxidant capacity of cattle fed BPER diets was not improved. Similarly, Maciej et al. (2016) reported that oral flavonoid supplementation did not have any effect on the plasma anti- 
oxidant capacity of newborn dairy cattle. Hosoda et al. (2012a) demonstrated that feeding anthocyanin-rich corn silage did not enhance plasma total antioxidant status in lactating dairy cows. Hosoda et al. (2012b) showed that supplementation of purple pigment from anthocyanin-rich corn did not enhance plasma total antioxidant capacity in sheep. When the level of antioxidants is low, their contributions to antioxidant capacity probably has little influence compared to endogenous antioxidative defense (Matthaiou et al., 2014). The amount of BPER intake and/or period of experimentation could be limiting factors to improve antioxidant capacity. In addition, the small number of cattle replication $(n=4)$ and endogenous antioxidant enzyme strong activity of young animal (Hatao et al., 2006) might had influence on the not significant effect on the plasma antioxidant capacity of this study.

The MDA and protein carbonyl in plasma are byproducts derived from lipid and protein oxidations, respectively. This study demonstrated that the decreased MDA and protein carbonyl in plasma of cattle supplemented with more BPER in diets did not correlate with plasma total antioxidant.

The total antioxidant activity, which was not significantly different between treatments, showed the dominant effect of endogenous antioxidants. The decreasing levels of MDA and protein carbonyl showed the effect of antioxidant, anthocyanins, and phenolic acid (Ramos-Escudero et al., 2012). The antioxidant effect of anthocyanin and phenolic did not have a significant effect on total antioxidant activity, presumably because the treatment level was not adequate. This is evidenced by a significant decrease in MDA and a tendency to decrease in protein carbonyl at the BPER level of $6 \%$, but it has not had a significant effect on total antioxidant activity. This could be due to the activation of endogenous antioxidant enzymes affected by anthocyanins and phenolic acid on antioxidant status in the cell systems (Villasante et al., 2016).

It has been reported that feeding natural flavonoid substances to animals significantly increased plasma superoxide dismutase (SOD) activity and decreased plasma MDA (Hosoda et al., 2012a; Hosoda et al., 2012b; Safari et al., 2018; Nurrofingah et al., 2020). Safari et al. (2018) demonstrated that phenolic acid from pomegranate by-products in diets of dairy cows had a positive effect on blood antioxidant by increasing blood antioxidant capacity and decreasing blood MDA concentration. Matsuba et al. (2019) who fed TMR purple corn silage (anthocyanins at $20-70 \mathrm{mg} / \mathrm{kg}$ ) on lactating cows increased blood superoxide dismutase concentration. Similarly, the ingestion of conventional and organic red grape juice-rich polyphenols in humans decreased MDA values of plasma (Toaldo et al., 2015).

\section{CONCLUSION}

The BPER supplementation up to $6 \%$ in the diet of male dairy cattle did not have any effect on feed intake, nutrient digestibility, and growth performance. There was no effect of BPER on metabolite, protein carbonyl, and antioxidant activity in plasma. However, the cattle fed BPER presented lower lipid oxidation in plasma. This indicates that BPER can be beneficial for health promotion by reducing oxidative stress in male dairy cattle.

\section{CONFLICT OF INTEREST}

The authors declare that they have no conflict of interest.

\section{ACKNOWLEDGEMENT}

The authors would like to express their most sincere thanks to the financial support from the Thailand Research Fund through the Royal Golden Jubilee Ph.D. Program (Grant No. PHD/0194/2556). The Increased Production Efficiency and Meat Quality of Native Beef and Buffalo Research Group, Khon Kaen University, is acknowledged for some financial support in the feeding trial.

\section{REFERENCES}

Ainsworth, E. A. \& K. M. Gillespie. 2007. Estimation of total phenolic content and other oxidation substrates in plant tissues using Folin-Ciocalteu reagent. Nat. Protoc. 2:875877. https://doi.org/10.1038/nprot.2007.102

Akbarian, A., J. Michiels, J. Degroote, M. Majdeddin, A. Golian, \& S. De Smet. 2016. Association between heat stress and oxidative stress in poultry; mitochondrial dysfunction and dietary interventions with phytochemicals. J. Anim. Sci. Biotechnol. 7:37. https://doi.org/10.1186/ s40104-016-0097-5

AOAC. 1995. Official methods of analysis $16^{\text {th }}$ Ed. Assoc. Off. Anal. Chem., Washington DC, USA.

Bendokas, V., V. Stanys, I. Mažeikienė, S. Trumbeckaite, R. Baniene, \& J. Liobikas. 2020. Anthocyanins: From the Field to the Antioxidants in the Body. Antioxidants. 9:819. https://doi.org/10.3390/antiox9090819

Butt, M. A., J. A. Bhatti, A. Khalique, \& M. Q. Shahid. 2019. Effect of fat supplementation on physiological and reproductive performance of Holstein Friesian bulls during summer. Trop. Anim. Health Prod. 51:2595-2601. https:// doi.org/10.1007/s11250-019-01976-1

Cömert, E. D., B. A. Mogol, \& V. Gökmen. 2020. Relationship between color and antioxidant capacity of fruits and vegetables. Curr. Res. Food Sci. 2:1-10. https://doi.org/10.1016/j. crfs.2019.11.001

de Souza, J., F. Batistel, K. C. Welter, M. M. Silva, D. F. Costa, \& F. A. Portela Santos. 2015. Evaluation of external markers to estimate fecal excretion, intake, and digestibility in dairy cows. Trop. Anim. Health Prod. 47:265-268. https:// doi.org/10.1007/s11250-014-0674-6

Fang, Y.-Z., S. Yang, \& G. Wu. 2002. Free radicals, antioxidants, and nutrition. Nutrition. 18:872-879. https://doi. org/10.1016/S0899-9007(02)00916-4

Fei, P., F. Zeng, S. Zheng, Q. Chen, Y. Hu, \& J. Cai. 2021. Acylation of blueberry anthocyanins with maleic acid: Improvement of the stability and its application potential in intelligent color indicator packing materials. Dye. Pigment. 184:108852. https://doi.org/10.1016/j. dyepig.2020.108852

Fenton, T. W. \& M. Fenton. 1979. An improved procedure for the determination of chromic oxide in feed and feces. Can. J. Anim. Sci. 59:631-634. https://doi.org/10.4141/cjas79-081

Gerber, P. J., A. Uwizeye, R. P. O. Schulte, C. I. Opio, \& I. J. M. de Boer. 2014. Nutrient use efficiency: A valuable approach to benchmark the sustainability of nutrient use in 
global livestock production. Curr. Opin. Environ. Sustain. 9:122-130. https://doi.org/10.1016/j.cosust.2014.09.007

Hassan, A. A., A. Z. M. Salem, A. E. Kholif, M. Samir, M. H. Yacout, S. H. A. Hafsa, G. D. Mendoza, M. M. Y. Elghandour, M. Ayala, \& S. Lopez. 2016. Performance of crossbred dairy Friesian calves fed two levels of Saccharomyces cerevisiae: intake, digestion, ruminal fermentation, blood parameters and faecal pathogenic bacteria. J. Agric. Sci. 154:1488-1498. https://doi.org/10.1017/ S0021859616000599

Hatao, H., S. Oh-Ishi, M. Itoh, C. Leeuwenburgh, H. Ohno, T. Ookawara, K. Kishi, H. Yagyu, H. Nakamura, \& T. Matsuoka. 2006. Effects of acute exercise on lung antioxidant enzymes in young and old rats. Mech. Ageing Dev. 127:384-390. https://doi.org/10.1016/j.mad.2005.12.008

Hosoda, K., B. Eruden, H. Matsuyama, \& S. Shioya. 2012a. Effect of anthocyanin-rich corn silage on digestibility, milk production and plasma enzyme activities in lactating dairy cows. Anim. Sci. J. 83:453-459. https://doi. org/10.1111/j.1740-0929.2011.00981.x

Hosoda, K., M. Miyaji, H. Matsuyama, S. Haga, H. Ishizaki, \& K. Nonaka. 2012b. Effect of supplementation of purple pigment from anthocyanin-rich corn (Zea mays L.) on blood antioxidant activity and oxidation resistance in sheep. Livest. Sci. 145:266-270. https://doi.org/10.1016/j. livsci.2011.12.001

Ishida, K., Y. Kishi, K. Oishi, H. Hirooka, \& H. Kumagai. 2015. Effects of feeding polyphenol-rich winery wastes on digestibility, nitrogen utilization, ruminal fermentation, antioxidant status and oxidative stress in wethers. Anim. Sci. J. 86:260-269. https://doi.org/10.1111/asj.12280

Kapcum, N., J. Uriyapongson, I. Alli, \& S. Phimphilai. 2016. Anthocyanins, phenolic compounds and antioxidant activities in colored corn cob and colored rice bran. Int. Food Res. J. 23:2347-2356.

Kirisattayakul, W., J. Wattanathorn, S. Iamsaard, J. Jittiwat, B. Suriharn, \& K. Lertrat. 2017. Neuroprotective and memory-enhancing effect of the combined extract of purple waxy corn cob and pandan in ovariectomized rats. Oxid. Med. Cell. Longev. 2017:1-12. https://doi. org/10.1155/2017/5187102

Laokuldilok, T., C. F. Shoemaker, S. Jongkaewwattana, \& V. Tulyathan. 2011. Antioxidants and antioxidant activity of several pigmented rice brans. J. Agric. Food Chem. 59:193199. https://doi.org/10.1021/jf103649q

Lee, J., R. W. Durst, \& R. E. Wrolstad. 2005. Determination of total monomeric anthocyanin pigment content of fruit juices, beverages, natural colorants, and wines by the $\mathrm{pH}$ differential method: c. J. AOAC Int. 88:1269-1278. https:// doi.org/10.1093/jaoac/88.5.1269

Levine, R. L., J. A. Williams, E. P. Stadtman, \& E. Shacter. 1994. Carbonyl assays for determination of oxidatively modified proteins. Methods Enzymol. 233:346-357. https://doi. org/10.1016/S0076-6879(94)33040-9

Maciej, J., C. T. Schäff, E. Kanitz, A. Tuchscherer, R. M. Bruckmaier, S. Wolffram, \& H. M. Hammon. 2016. Short communication: Effects of oral flavonoid supplementation on the metabolic and antioxidative status of newborn dairy calves. J. Dairy Sci. 99:805-811. https://doi.org/10.3168/ jds.2015-9906

Martinez, S., L. Valek, J. Rešetić, \& D. F. Ružić. 2006. Cyclic voltammetry study of plasma antioxidant capacity Comparison with the DPPH and TAS spectrophotometric methods. J. Electroanal. Chem. 588:68-73. https://doi. org/10.1016/j.jelechem.2005.12.016

Matthaiou, C. M., N. Goutzourelas, D. Stagos, E. Sarafoglou, A. Jamurtas, S. D. Koulocheri, S. A. Haroutounian, A. M. Tsatsakis, \& D. Kouretas. 2014. Pomegranate juice consumption increases GSH levels and reduces lipid and protein oxidation in human blood. Food Chem. Toxicol. 73:1-6. https://doi.org/10.1016/j.fct.2014.07.027

Matsuba, T., H. Kubozono, A. Saegusa, K. Obata, K. Gotoh, K. Miki, T. Akiyama, \& M. Oba. 2019. Short communication: Effects of feeding purple corn (Zea mays L.) silage on productivity and blood superoxide dismutase concentration in lactating cows. J. Dairy Sci. 102:7179-7182. https://doi. org/10.3168/jds.2019-16353

Modzelewska-Kapituła, M., K. Tkacz, Z. Nogalski, M. Karpińska-Tymoszczyk, A. Draszanowska, R. PietrzakFiećko, C. Purwin, \& K. Lipiński. 2018. Addition of herbal extracts to the Holstein-Friesian bulls' diet changes the quality of beef. Meat Sci. 145:163-170. https://doi. org/10.1016/j.meatsci.2018.06.033

NRC. 2001. Nutrient requirement of dairy cattle, 7th revised edn. National Research Council National Academy Press, Washington, DC. USA.

Nurrofingah, U., S. Sumiati, \& Y. Retnani. 2020. Evaluation of sweet potato leaves and cassava leaves inclusions into the diet containing lemuru oil on lipid metabolism in local duck. Trop. Anim. Sci. J. 43:141-150. https://doi. org/10.5398/tasj.2020.43. 2.141

Oliveira, R. A., C. D. Narciso, R. S. Bisinotto, M. C. Perdomo, M. A. Ballou, M. Dreher, \& J. E. P. Santos. 2010. Effects of feeding polyphenols from pomegranate extract on health, growth, nutrient digestion, and immunocompetence of calves. J. Dairy Sci. 93:4280-4291. https://doi.org/10.3168/ jds.2010-3314

Palungwachira, P., S. Tancharoen, P. Dararat, \& T. Nararatwanchai. 2020. Anthocyanins isolated from Oryza sativa L. protect dermal fibroblasts from hydrogen peroxide-induced cell death. J. Nat. Sci. Biol. Med. 11:45. https:// doi.org/10.4103/jnsbm.JNSBM_171_19

Park, S. Y., J. W. Lee, G. W. Kim, \& H. Y. Kim. 2017. Effect of black rice powder on the quality properties of pork patties. Korean J. Food Sci. Anim. Resour. 37:71-78. https://doi. org/10.5851/kosfa.2017.37.1.71

Patsoukis, N., G. Zervoudakis, N. T. Panagopoulos, C. D. Georgiou, F. Angelatou, \& N. A. Matsokis. 2004. Thiol redox state (TRS) and oxidative stress in the mouse hippocampus after pentylenetetrazol-induced epileptic seizure. Neurosci. Lett. 357:83-86. https://doi.org/10.1016/j. neulet.2003.10.080

Pereira, D. H., O. G. Pereira, B. C. Silva, M. I. Leão, S. C. Valadares Filho, \& R. Garcia. 2008. Nutrient intake and digestibility and ruminal parameters in beef cattle fed diets containing Brachiaria brizantha silage and concentrate at different ratios. Anim. Feed Sci. Technol. 140:52-66. https:// doi.org/10.1016/j.anifeedsci.2007.02.012

Prommachart, R., T. S. Belem, S. Uriyapongson, P. RayasDuarte, J. Uriyapongson, \& R. Ramanathan. 2020. The effect of black rice water extract on surface color, lipid oxidation, microbial growth, and antioxidant activity of beef patties during chilled storage. Meat Sci. 164: 108091. https://doi.org/10.1016/j.meatsci.2020.108091

Purba, N. S., S. Uriyapongson, \& J. Uriyapongson. 2020. Effect of purple corn cob extract powder and black rice bran oil on quality and shelf life of fresh beef. Songklanakarin J. Sci. Technol. 42:645-651.https://doi:10.14456/SJST-PSU.2020.82.

Ramos-Escudero, F., A. M. Muñoz, C. Alvarado-Ortíz, Á. Alvarado, \& J. A. Yáñez. 2012. Purple corn ( Zea mays L.) phenolic compounds profile and its assessment as an agent against oxidative stress in isolated mouse organs. J. Med. Food. 15:206-215. https://doi.org/10.1089/jmf.2010.0342

Ribeiro, J. S., M. J. M. C. Santos, L. K. R. Silva, L. C. L. Pereira, I. A. Santos, S. C. da Silva Lannes, \& M. V. da Silva. 2019. Natural antioxidants used in meat products: A brief review. Meat Sci. 148:181-188. https://doi.org/10.1016/j. meatsci.2018.10.016 
Safari, M., E. Ghasemi, M. Alikhani, \& S. Ansari-Mahyari. 2018. Supplementation effects of pomegranate by-products on oxidative status, metabolic profile, and performance in transition dairy cows. J. Dairy Sci. 101:1129711309. https://doi.org/10.3168/jds.2018-14506

Sangkitikomol, W., T. Tencomnao, \& A. Rocejanasaroj. 2010. Effects of Thai black sticky rice extract on oxidative stress and lipid metabolism gene expression in HepG2 cells. Genet. Mol. Res. 9:2086-2095. https://doi.org/10.4238/ vol9-4gmr912

SAS. 1998. User's Guide: Statistic, Version 6, $12^{\text {th }}$ Ed. SAS Inst. Inc. Cary, NC.

Šturm, L. \& N. Poklar Ulrih. 2020. Propolis flavonoids and terpenes, and their interactions with model lipid membranes: A review. Adv. Biomembr. Lipid Self-Assembly. 32:25-52. https://doi.org/10.1016/bs.abl.2020.04.003

Tan, C., C. A. Ramírez-Restrepo, A. M. Shah, R. Hu, M. Bell, Z. Wang, \& C. McSweeney. 2020. The community structure and microbial linkage of rumen protozoa and methanogens in response to the addition of tea seed saponins in the diet of beef cattle. J. Anim. Sci. Biotechnol. 11:80. https:// doi.org/10.1186/s40104-020-00491-w

Tarahovsky, Y. S., Y. A. Kim, E. A. Yagolnik, \& E. N. Muzafarov. 2014. Flavonoid-membrane interactions: Involvement of flavonoid-metal complexes in raft signaling. Biochim. Biophys. Acta - Biomembr. 1838:1235-1246. https://doi. org/10.1016/j.bbamem.2014.01.021

Tian, X., P. Paengkoum, S. Paengkoum, S. Thongpea, \& C. Ban. 2018. Comparison of forage yield, silage fermentative quality, anthocyanin stability, antioxidant activity, and in vitro rumen fermentation of anthocyanin-rich purple corn (Zea mays L.) stover and sticky corn stover. J. Integr. Agric. 17:2082-2095. https://doi.org/10.1016/ S2095-3119(18)61970-7

Tian, X., H. Xin, P. Paengkoum, S. Paengkoum, C. Ban. \& S. Thongpea. 2019. Effects of anthocyanin-rich purple corn (Zea mays L.) stover silage on nutrient utilization, rumen fermentation, plasma antioxidant capacity, and mammary gland gene expression in dairy goats. J. Anim. Sci. 97:13841397. https://doi.org/10.1093/jas/sky477

Toaldo, I. M., F. A. Cruz, T. de L. Alves, J. S. de Gois, D. L. G.
Borges, H. P. Cunha, E. L. da Silva, \& M. T. BordignonLuiz. 2015. Bioactive potential of Vitis labrusca L. grape juices from the Southern Region of Brazil: Phenolic and elemental composition and effect on lipid peroxidation in healthy subjects. Food Chem. 173:527-535. https://doi. org/10.1016/j.foodchem.2014.09.171

Trikas, E. D., M. Melidou, R. M. Papi, G. A. Zachariadis, \& D. A. Kyriakidis. 2016. Extraction, separation and identification of anthocyanins from red wine by-product and their biological activities. J. Funct. Foods. 25:548-558. https:// doi.org/10.1016/j.jff.2016.06.033

Van Soest, P. J., J. B. Robertson, \& B. A. Lewis. 1991. Methods for dietary fiber, neutral detergent fiber, and nonstarch polysaccharides in relation to animal nutrition. J. Dairy Sci. 74:3583-3597. https://doi.org/10.3168/jds. S0022-0302(91)78551-2

Van Soest, P. J. \& J. B. Robertson. 1980. Systems of Analysis for Evaluating Fibrous Feeds. In: Pigden, W. J., Balch, C. C., Graham, M. (Eds.), Standardization of Analytical Methodology for Feeds. International Development Research Centre, Ottawa, Canada, p. 49-60.

Villasante, A., M. S. Powell, K. Moutou, G. K. Murdoch, K. Overturf, J. Wacyk, \& R. W. Hardy. 2016. Effects of anthocyanidins on myogenic differentiation and antioxidant defense in primary myogenic cells isolated from rainbow trout (Oncorhynchus mykiss). Aquaculture. 454:81-89. https://doi.org/10.1016/j.aquaculture.2015.12.007

Williams, C. H., D. J. David, \& O. Iismaa. 1962. The determination of chromic oxide in faeces samples by atomic absorption spectrophotometry. J. Agric. Sci. 59:381-385. https:// doi.org/10.1017/S002185960001546X

Yamashita, C., M. M. S. Chung, C. dos Santos, C. R. M. Mayer, I. C. F. Moraes, \& I. G. Branco. 2017. Microencapsulation of an anthocyanin-rich blackberry (Rubus spp.) by-product extract by freeze-drying. LWT - Food Sci. Technol. 84:256262. https://doi.org/10.1016/j.lwt.2017.05.063

Zhao, X., C. Zhang, C. Guigas, Y. Ma, M. Corrales, B. Tauscher, \& X. Hu. 2009. Composition, antimicrobial activity, and antiproliferative capacity of anthocyanin extracts of purple corn (Zea mays L.) from China. Eur. Food Res. Technol. 228:759-765. https://doi.org/10.1007/s00217-008-0987-7 